\title{
Races of Isolates of Plasmopara halstedii from Spain and Studies on Their Virulence
}

\author{
M. L. Molinero-Ruiz, Department of Crop Protection, Instituto de Agricultura Sostenible-CSIC, Cordoba, Spain; \\ J. Domínguez, Department of Breeding and Agronomy, CIFA-Cordoba, Cordoba, Spain; and J. M. Melero-Vara, \\ Department of Crop Protection, Instituto de Agricultura Sostenible-CSIC, Cordoba, Spain
}

\begin{abstract}
Molinero-Ruiz, M. L., Domínguez, J., and Melero-Vara, J. M. 2002. Races of isolates of Plasmopara halstedii from Spain and studies on their virulence. Plant Dis. 86:736-740.

Plants infected with downy mildew were collected from 1994 to 2000 in sunflower fields in Spain. The race of 102 bulk isolates of Plasmopara halstedii obtained from them was determined by inoculation of sunflower lines traditionally used as differentials for characterization of the pathogen. Nine different races of the fungus were determined. Although race 1 was most common and was the only one found in central Spain, races 4, 6, and 7 were widespread in southern Spain. The results allowed the identification of a new race of the pathogen, race 10, and of a race not previously reported in Europe, race 8. According to the proposal of a new system for characterization of the isolates of $P$. halstedii in the late 1990s, Coded Virulence Formulae (CVF) were assigned to bulk isolates and single-sporangium (ss) isolates obtained from them. The CVF of the bulk isolates (CVFi) did not always fit with the previous designation. Similarly, ss isolates from the same bulk isolate exhibited different CVF, not only among themselves, but also compared with the CVF of the source isolate. Although a revision of the differential lines used to perform the racial characterization of fungal isolates seems to be needed, the occurrence of a diversity of genotypes in field populations of $P$. halstedii and a high frequency of recombination and/or mutation of the fungal genome is also suggested.
\end{abstract}

Additional keywords: genetic resistance, Helianthus annuиs

Downy mildew of sunflower (SDM) is a common disease in many areas of the world where sunflowers (Helianthus annuus L.) are grown. It is caused by the fungus Plasmopara halstedii (Farl.) Berl. $\&$ de Toni in Sacc. and infects young plants in spring when soil moisture is high and temperatures range from 15 to $18^{\circ} \mathrm{C}$. The systemic infection of seedlings can be caused by both zoospores (asexual spores, mainly located on the underside of the leaves) and oospores (resting structures, mainly formed on the roots). Control of the disease is achieved primarily through genetic resistance.

The disease was first described in Spain in the 1970s, the European race (race 1 or 100) being the only race of the pathogen identified in the country $(11,12)$. Race Red River (race 2 or 300) was first found in North Dakota and Minnesota. Resistance to these races is controlled by two genes: $\mathrm{Pl}_{1}$ and $P l_{2}$, and both (together or independently) were incorporated into downy

Corresponding author: J. M. Melero-Vara

E-mail: cs9mevaj@uco.es

Accepted for publication 27 February 2002.

Publication no. D-2002-0426-01R

This article is in the public domain and not copyrightable. It may be freely reprinted with customary crediting of the source. The American Phytopathological Society, 2002. mildew resistant sunflower hybrids $(2,21$, 22,26-28). During the last 20 years, seven new races of the pathogen have been identified in North America and several European countries $(1,3-5,8,10,14,18,19,23,24)$. These new races are more virulent than the previous ones (race 100 in Europe and race 300 in North America) and have overcome the resistance genes $P l_{l}$ and $P l_{2}$. Identification of SDM infections in resistant hybrids in Spain suggested that characterization of isolates of the fungus from Spain to race should be conducted. Previous research has been presented $(15,16)$.

Different races of $P$. halstedii have been identified through the resistant/susceptible reactions of sunflower lines used as differentials. Nevertheless, this system has become too complex and confusing, since many isolates of different virulence are being continuously identified, thus requiring the use of many differential lines. Recently, the virulence of SDM isolates has been determined by means of a Coded Virulence Formula (CVF) obtained from the reactions of nine differential lines (9). The CVF has three digits, corresponding to the three sets of differentials tested. The first, second, and third differential of each set is assigned the values of 1,2 , and 4 , respectively, only if the reaction is susceptible. All resistant reactions are assigned the value of 0 . The sum of the values for the set equals the digit for that set (13). This nomenclature system is more dynamic than race enumeration and is still compatible with former identifications.

The objectives of this research were: (i) to determine the race(s) of SDM bulk isolates collected in Spain, using both the traditional and the CVF systems, and (ii) to characterize the virulence of singlesporangium (ss) isolates using the CVF system, in order to compare it with the virulence of the corresponding SDM bulk isolate.

\section{MATERIALS AND METHODS}

Inoculum preparation. Field samples (110) of the pathogen were collected from commercial fields and breeding nurseries of sunflower in different locations in Spain from 1994 to 2000. The zoospores of the pathogen were recovered directly from individual plants that showed pathogen sporulation on leaves, or after 24 to $48 \mathrm{~h}$ of incubation in a humid chamber at $15^{\circ} \mathrm{C}$ in the dark. The inoculum was a zoosporangial suspension in deionized water filtered through sterile gauze. Its concentration was adjusted to $1.50 \times 10^{5}$ sporangia per $\mathrm{ml}$ with a hemacytometer.

To increase the initial inoculum, 30 seedlings of the susceptible cultivar Peredovik were inoculated with each SDM sample. Sunflower seeds were surfacesterilized by immersing them in $10 \%$ sodium hypochlorite for 5 to $10 \mathrm{~min}$, then thoroughly rinsed in deionized water and incubated in the dark at saturation in a germinator at 24 to $28^{\circ} \mathrm{C}$ until radicles were 2 to $5 \mathrm{~mm}$ long. The seedlings were immersed in the zoosporangial suspension for 4 to $5 \mathrm{~h}$ at $15^{\circ} \mathrm{C}$. Inoculated seedlings were sown in a sand:perlite mixture $(2: 3$, $\mathrm{vol} / \mathrm{vol})$ and kept in a growth chamber (16 to $21^{\circ} \mathrm{C}$ and a 12 -h photoperiod, with light irradiance of $100 \mu \mathrm{E} \cdot \mathrm{m}^{-2} \cdot \mathrm{s}^{-1}$ ) for 10 to 12 days until expansion of the first pair of true leaves. Plants were incubated for $48 \mathrm{~h}$ at $100 \%$ relative humidity $(\mathrm{RH})$ and the same conditions of temperature and light, in order to allow pathogen sporulation. Zoospores were used as inoculum for subsequent tests.

Racial characterization. Fifteen to 20 seedlings of each of the sunflower differentials were inoculated and incubated as described previously. The intense sporulation on cotyledons and/or first pair of true leaves was indicative of a susceptible reaction. Resistance was recorded by the absence of sporulation or when weak sporula- 
tion, often simultaneous with a hypersensitive reaction, was observed only on cotyledons. All the inoculations were performed twice, and when a resistant/ susceptible reaction was doubtful, it was repeated a third time.

Characterization of virulence. The CVF of 19 bulk isolates of $P$. halstedii (CVFi) was determined after the inoculation of the three sets of sunflower lines used as differentials. Germination, inoculation, and growth of the seedlings were performed as for race characterization. Deionized water used for the preparation of inoculum suspensions was amended with calcium chloride $\left(\mathrm{CaCl}_{2} \cdot 2 \mathrm{H}_{2} \mathrm{O}\right)$ to achieve a concentration of $140 \mathrm{ppm}$ of calcium. Riboflavin was added to the inoculum suspension at $2.5 \times 10^{-5} \mathrm{~g} / \mathrm{ml}$ to induce activity of zoospores. For each isolate, 12 seedlings of each differential were incubated in the inoculum suspension in darkness at $15^{\circ} \mathrm{C}$ for 4 to $5 \mathrm{~h}$ before sowing in the sand:perlite mixture. Thereafter, plants were grown under greenhouse conditions (20 to $24^{\circ} \mathrm{C}$ and 12 - to $16-\mathrm{h}$ photoperiod, with average irradiance of $\left.250 \mu \mathrm{E} \cdot \mathrm{m}^{-2} \cdot \mathrm{s}^{-1}\right)$. After 12 to 14 days, when the first true leaves were approximately 20 $\mathrm{mm}$ long, plants were placed in a chamber maintained at $16^{\circ} \mathrm{C}$ and $100 \% \mathrm{RH}$ for $16 \mathrm{~h}$ and evaluated for resistant or susceptible reaction.

Since the R/S reactions exhibited by the 16 differentials constituted the traditional method to identify races of $P$. halstedii, this was the method we first used. Following the proposed use of the CVF method (9), we again characterized the virulence of our isolates. According to the traditional nomenclature, one value of CVF corresponds to each of the races, and that is why there is a CVF value for the new race 10 . When
Table 2. Racial identification of isolates of Plasmopara halstedii from Spain and theoretical virulences (CVFt) associated with the races (1994 to 2000)

\begin{tabular}{|c|c|c|c|c|}
\hline Year & Number of isolates & Location $^{\mathrm{y}}$ & Race & $\mathrm{CVFt}^{\mathrm{z}}$ \\
\hline 1994 & $\begin{array}{l}1 \\
1 \\
1 \\
2\end{array}$ & $\begin{array}{c}\text { Cordoba, S } \\
\text { Sevilla, S } \\
\text { Sevilla, S } \\
\text { Gerona, NE }\end{array}$ & $\begin{array}{c}4 \\
6 \\
7 \\
10\end{array}$ & $\begin{array}{c}730 \\
310 \\
330 \\
-\end{array}$ \\
\hline 1995 & $\begin{array}{l}1 \\
2 \\
2 \\
1 \\
2 \\
3 \\
7 \\
3\end{array}$ & $\begin{array}{c}\text { Cordoba, S } \\
\text { Guadalajara, C } \\
\text { Sevilla, S } \\
\text { Sevilla, S } \\
\text { Sevilla, S } \\
\text { Sevilla, S } \\
\text { Cordoba, S } \\
\text { Gerona, NE }\end{array}$ & $\begin{array}{c}1 \\
1 \\
1 \\
2 \\
4 \\
6 \\
7 \\
10\end{array}$ & $\begin{array}{c}100 \\
100 \\
100 \\
300 \\
730 \\
310 \\
330 \\
-\end{array}$ \\
\hline 1996 & $\begin{array}{l}7 \\
4 \\
3 \\
8 \\
1 \\
1 \\
1 \\
1\end{array}$ & $\begin{array}{c}\text { Cadiz, S } \\
\text { Cordoba, S } \\
\text { Cuenca, C } \\
\text { Guadalajara, C } \\
\text { Sevilla, S } \\
\text { Sevilla, S } \\
\text { Cordoba, S } \\
\text { Sevilla, S }\end{array}$ & $\begin{array}{l}1 \\
1 \\
1 \\
1 \\
1 \\
4 \\
5 \\
6\end{array}$ & $\begin{array}{l}100 \\
100 \\
100 \\
100 \\
100 \\
730 \\
770 \\
310\end{array}$ \\
\hline 1997 & $\begin{array}{l}2 \\
2 \\
1 \\
3 \\
5 \\
2 \\
5\end{array}$ & $\begin{array}{c}\text { Cadiz, S } \\
\text { Guadalajara, C } \\
\text { Zaragoza, C } \\
\text { Sevilla, S } \\
\text { Sevilla, S } \\
\text { Badajoz, C } \\
\text { Sevilla, S }\end{array}$ & $\begin{array}{l}1 \\
1 \\
1 \\
4 \\
6 \\
7 \\
7\end{array}$ & $\begin{array}{l}100 \\
100 \\
100 \\
730 \\
310 \\
330 \\
330\end{array}$ \\
\hline 1998 & $\begin{array}{l}2 \\
3 \\
3 \\
4\end{array}$ & $\begin{array}{c}\text { Sevilla, S } \\
\text { Cordoba, S } \\
\text { Sevilla, S } \\
\text { Cordoba, S }\end{array}$ & $\begin{array}{l}1 \\
4 \\
7 \\
8\end{array}$ & $\begin{array}{l}100 \\
730 \\
330 \\
710\end{array}$ \\
\hline 1999 & $\begin{array}{l}4 \\
2\end{array}$ & $\begin{array}{c}\text { Cordoba, S } \\
\text { Sevilla, S }\end{array}$ & $\begin{array}{l}1 \\
6\end{array}$ & $\begin{array}{l}100 \\
310\end{array}$ \\
\hline 2000 & $\begin{array}{l}1 \\
2 \\
5 \\
5 \\
3 \\
2 \\
1 \\
1\end{array}$ & $\begin{array}{c}\text { Sevilla, S } \\
\text { Cordoba, S } \\
\text { Cordoba, S } \\
\text { Sevilla, S } \\
\text { Cordoba, S } \\
\text { Sevilla, S } \\
\text { Cordoba, S } \\
\text { Gerona, NE }\end{array}$ & $\begin{array}{c}2 \\
3 \\
6 \\
6 \\
7 \\
7 \\
8 \\
10\end{array}$ & $\begin{array}{c}300 \\
700 \\
310 \\
310 \\
330 \\
330 \\
710 \\
-\end{array}$ \\
\hline
\end{tabular}

y $\mathrm{S}=$ south, $\mathrm{NE}=$ northeast, $\mathrm{C}=$ center

${ }^{\mathrm{z}}$ No value of CVFt could be assigned to isolates of race 10 , since it is a new race.

Table 1. Reactions of differential sunflower lines to races of Plasmopara halstedii ${ }^{\mathrm{w}}$

\begin{tabular}{|c|c|c|c|c|c|c|c|c|c|c|}
\hline \multirow[b]{2}{*}{ Differential lines $^{x}$} & \multicolumn{10}{|c|}{ Races of $P$. halstedii } \\
\hline & 1 & 2 & 3 & 4 & 5 & 6 & 7 & 8 & 9 & $10^{y}$ \\
\hline Peredovik & $\mathrm{S}^{\mathrm{z}}$ & S & S & $\mathrm{S}$ & $\mathrm{S}$ & $S$ & $S$ & S & S & $\mathrm{S}$ \\
\hline IS003 & $\mathrm{S}$ & $\mathrm{S}$ & $\mathrm{S}$ & $\mathrm{S}$ & $\mathrm{S}$ & $\mathrm{S}$ & $\mathrm{S}$ & $\mathrm{S}$ & $\mathrm{S}$ & $\mathrm{S}$ \\
\hline HA-304 & $\mathrm{S}$ & $\mathrm{S}$ & $\mathrm{S}$ & $\mathrm{S}$ & $\mathrm{S}$ & $\mathrm{S}$ & $\mathrm{S}$ & $\mathrm{S}$ & $\mathrm{S}$ & $\mathrm{S}$ \\
\hline RHA-265 & $\mathrm{R}$ & $\mathrm{S}$ & $\mathrm{S}$ & $\mathrm{S}$ & $\mathrm{S}$ & $\mathrm{S}$ & $\mathrm{S}$ & $\mathrm{S}$ & $\mathrm{S}$ & $\mathrm{S}$ \\
\hline RHA-266 & $\mathrm{R}$ & $\mathrm{S}$ & $\mathrm{S}$ & $\mathrm{S}$ & $\mathrm{S}$ & $\mathrm{S}$ & $\mathrm{S}$ & $\mathrm{S}$ & $\mathrm{S}$ & $\mathrm{S}$ \\
\hline RHA-274 & $\mathrm{R}$ & $\mathrm{R}$ & $\mathrm{S}$ & $\mathrm{S}$ & $\mathrm{S}$ & $\mathrm{R}$ & $\mathrm{R}$ & $S$ & $\mathrm{R}$ & $\mathrm{S}$ \\
\hline HA-61 & $\mathrm{R}$ & $\mathrm{R}$ & $\mathrm{S}$ & $\mathrm{S}$ & $\mathrm{S}$ & $\mathrm{R}$ & $\mathrm{R}$ & $\mathrm{S}$ & $\mathrm{R}$ & $\mathrm{S}$ \\
\hline DM-2 & $\mathrm{R}$ & $\mathrm{R}$ & $\mathrm{R}$ & $\mathrm{S}$ & $\mathrm{S}$ & $\mathrm{S}$ & $\mathrm{S}$ & $\mathrm{S}$ & $\mathrm{S}$ & $\mathrm{R}$ \\
\hline PM13 & $\mathrm{R}$ & $\mathrm{R}$ & $\mathrm{R}$ & $\mathrm{S}$ & $\mathrm{S}$ & $\mathrm{S}$ & $\mathrm{S}$ & $\mathrm{S}$ & $\mathrm{S}$ & $\mathrm{R}$ \\
\hline RHA-325 & $\mathrm{R}$ & $\mathrm{R}$ & $\mathrm{S}$ & $\mathrm{S}$ & $\mathrm{S}$ & $\mathrm{S}$ & $\mathrm{R}$ & $\mathrm{S}$ & $\mathrm{R}$ & $\mathrm{S}$ \\
\hline $799-1$ & $\mathrm{R}$ & $\mathrm{R}$ & $\mathrm{R}$ & $\mathrm{S}$ & $\mathrm{S}$ & $\mathrm{R}$ & $?$ & $\mathrm{R}$ & $\mathrm{S}$ & $\mathrm{R}$ \\
\hline 803-1 & $\mathrm{R}$ & $\mathrm{R}$ & $\mathrm{R}$ & $\mathrm{R}$ & $\mathrm{S}$ & $\mathrm{R}$ & $\mathrm{R}$ & $\mathrm{R}$ & $\mathrm{R}$ & $\mathrm{R}$ \\
\hline HA-R4 & $\mathrm{R}$ & $\mathrm{R}$ & $\mathrm{R}$ & $\mathrm{R}$ & $\mathrm{R}$ & $\mathrm{R}$ & $\mathrm{R}$ & $\mathrm{R}$ & $\mathrm{R}$ & $\mathrm{S}$ \\
\hline HA-R5 & $\mathrm{R}$ & $\mathrm{R}$ & $\mathrm{R}$ & $\mathrm{R}$ & $\mathrm{R}$ & $\mathrm{R}$ & $\mathrm{R}$ & $\mathrm{R}$ & $\mathrm{R}$ & $\mathrm{S}$ \\
\hline QHP1 & $\mathrm{R}$ & $\mathrm{R}$ & $\mathrm{R}$ & $\mathrm{R}$ & $\mathrm{R}$ & $\mathrm{R}$ & $\mathrm{R}$ & $\mathrm{R}$ & $\mathrm{R}$ & $\mathrm{S}$ \\
\hline RHA-340 & $\mathrm{R}$ & $\mathrm{R}$ & $\mathrm{R}$ & $\mathrm{R}$ & $\mathrm{R}$ & $\mathrm{R}$ & $\mathrm{R}$ & $\mathrm{R}$ & $\mathrm{R}$ & $\mathrm{R}$ \\
\hline
\end{tabular}

${ }^{\text {w }}$ Based on Gulya et al. $(6,8)$.

${ }^{x}$ Sunflower lines RHA-265 and RHA-266, and RHA-274 and HA-61, apparently have the same pattern of resistance to the fungus. We used RHA-266 and HA-61 for characterization of races, whereas RHA-265 and RHA-274 are used at USDA-ARS (Fargo, ND). Sunflower genotypes Peredovik, IS003, and HA-304 are susceptible to all known races. PM13 and DM-2 display the same susceptible/resistant pattern, and reactions of HA-R5 to different races are the same as those of QHP1.

${ }^{y}$ The new susceptible/resistant pattern of reactions of the 16 differentials inoculated allowed us to use the number 10 to designate the race.

${ }^{\mathrm{z}} \mathrm{S}=$ susceptible, $\mathrm{R}=$ resistant, ? = unknown reaction. 
we inoculated the differentials proposed by Gulya et al. (9), the CVF of some bulk isolates did not show the expected value. Therefore, we assigned theoretical $\mathrm{CVF}$ values $(\mathrm{CVFt})$ to those proposed by Gulya et al. (9) for each race, and isolate CVF $(\mathrm{CVFi})$ to the value we obtained for each isolate.

After the comparison of the CVFt and CVFi obtained for the 19 SDM isolates, ss cultures were attempted for 14 isolates. Twelve to 24 pregerminated and dehulled seeds of susceptible cultivar IS003 (Interstate Payco Seed Co., West Fargo, ND) were infected with each of the ss cultures. Each seed was placed in a glass vial containing $5 \mathrm{ml}$ of the calcium chloride solution amended with riboflavin as previously described, and a single sporangium was added. Individual sporangia were collected from a drop of diluted suspension $\left(<10^{3}\right.$ sporangia per $\mathrm{ml}$ ) of each isolate using capillary tubes under a stereoscope $(\times 20)$.
After incubation in darkness at $15^{\circ} \mathrm{C}$ for 4 $\mathrm{h}$, seeds were sown separately and grown for 12 to 14 days under the greenhouse conditions described above. When the pathogen sporulated, fungal structures from every plant were identified as different $s s$ cultures from the same bulk isolate. Each ss isolate was increased on 'IS003' prior to virulence characterization (CVFss) as previously described. Eight ss isolates were collected using a dry collector (7) and kept at $-80^{\circ} \mathrm{C}$ for 10 to 12 months before studying their virulence by thawing the inocula at room temperature before inoculating differentials.

\section{RESULTS}

Race characterization. The reactions of standard sunflower differential lines used for race characterization of $P$. halstedii are shown in Table 1. All of the differential lines exhibited some resistance to the fungus, except differentials Peredovik, IS003,

Table 3. Racial determination and Coded Virulence Formulae (CVF) of isolates of Plasmopara halstedii collected during 1994 to 1996 in different areas of Spain

\begin{tabular}{llccc}
\hline $\begin{array}{l}\text { Isolate of } \\
\text { P. halstedii }\end{array}$ & Location and year & Racial group $^{\mathbf{x}}$ & CVFt $^{\mathbf{y}}$ & CVFi $^{\mathbf{z}}$ \\
\hline R1094 & Gerona, 1994 & 10 & - & 703 \\
FA195 & Fuentes de Andalucia, Sevilla, 1995 & 1 & 100 & 330 \\
LC195 & La Carlota, Cordoba, 1995 & 1 & 100 & 310 \\
FA695 & Fuentes de Andalucia, Sevilla, 1995 & 6 & 310 & 330 \\
BA1095 & Bañolas, Gerona, 1995 & 10 & - & 703 \\
CA1095 & Castello, Gerona, 1995 & 10 & - & 703 \\
2AR196 & Aranzueque, Guadalajara, 1996 & 1 & 100 & 100 \\
4AR196 & Aranzueque, Guadalajara, 1996 & 1 & 100 & 100 \\
6AR196 & Aranzueque, Guadalajara, 1996 & 1 & 100 & 310 \\
8AR196 & Aranzueque, Guadalajara, 1996 & 1 & 100 & 310 \\
CA196 & Carrascosa, Cuenca, 1996 & 1 & 100 & 753 \\
CO196 & Montellano, Sevilla, 1996 & 1 & 100 & 100 \\
MO196 & Cordoba, 1996 & 1 & 100 & 100 \\
PA196 & Paterna, Cadiz, 1996 & 1 & 100 & 100 \\
1SA196 & Saelices, Cuenca, 1996 & 1 & 100 & 100 \\
2SA196 & Saelices, Cuenca, 1996 & 1 & 100 & 710 \\
SE196 & Sevilla, 1996 & 1 & 100 & 100 \\
EC496 & Ecija, Sevilla, 1996 & 4 & 730 & 310 \\
EC696 & Ecija, Sevilla, 1996 & 6 & 310 & 310 \\
\hline
\end{tabular}

${ }^{\mathrm{x}}$ Determined according to previous results of differentials.

y Theoretical CVF corresponding to the inoculation of three sets of differentials with $P$. halstedii isolates of the race listed in the previous column, except in the case of isolates of race 10 (new race).

${ }^{\mathrm{z}} \mathrm{CVF}$ obtained after the inoculation of the three sets of differentials with the given isolates. and HA-304, which are universally susceptible. The pathogenic characterization of 26 SDM isolates from 1994 and 1995 revealed that five (three from southern Spain and two from central Spain) collected in 1995 belonged to race 1 (Table 2). There was only one isolate of race 2 identified in southern Spain in 1995. Three isolates from this same area of the country were identified as race 4 (Table 2). Races 6 and 7 were also identified in both years: one isolate of each of the races in 1994, and three and seven isolates, respectively, in 1995 (Table 2). Five SDM isolates from northeastern Spain overcame resistance genes in RHA-266, HA-61, RHA-325, HA-R4, and HA-R5, but they did not induce sporulation on DM-2, 799-1, or 803-1 (Table 1). Therefore, they were referred to as race 10 (Table 2).

Most of the 26 SDM isolates from 1996 $(88 \%)$, including all the isolates from central Spain as well as some from southern Spain, were characterized as race 1 , as they did not overcome any of the resistance genes of the differentials (Tables 1 and 2). The remaining three SDM isolates from southern Spain were identified as races 4 , 5 , and 6 (Table 2).

Racial characterization was performed on 32 SDM isolates from 1997 and 1998. Race 7 was recovered most frequently (31\% of isolates) (Table 2). Races 1 and 4 were also identified in seven and six isolates, respectively (Table 2). Race 6 was only observed in 1997 (five isolates from southern Spain) (Table 2). Four SDM isolates from 1998 were characterized as race 8 , because they were pathogenic to all the differentials except 799-1 through RHA340 (Table 1).

Race 1 was most common among the isolates of 1999 (66\%), while the remaining isolates were identified as race 6 (Table 2 ). This race was also identified in $50 \%$ of the isolates in 2000. One isolate of each of the races 2,8 , and 10 was also identified, as well as five SDM isolates of race 7 (Table 2). The remaining two isolates induced symptoms on Peredovik through HA-61

Table 4. Reactions of differential sunflower lines to races of Plasmopara halstedii and the corresponding theoretical Coded Virulence Formulae (CVFt) ${ }^{\mathrm{z}}$

\begin{tabular}{|c|c|c|c|c|c|c|c|c|c|}
\hline \multirow[b]{2}{*}{ Differential line } & \multicolumn{9}{|c|}{ Reaction to races of $P$. halstedii } \\
\hline & 1 & 2 & 3 & 4 & 5 & 6 & 7 & 8 & 9 \\
\hline \multicolumn{10}{|l|}{ SET 1} \\
\hline HA-304 & $\mathrm{S}$ & $\mathrm{S}$ & $\mathrm{S}$ & $\mathrm{S}$ & $\mathrm{S}$ & $\mathrm{S}$ & $\mathrm{S}$ & $\mathrm{S}$ & $\mathrm{S}$ \\
\hline RHA-265 & $\mathrm{R}$ & $\mathrm{S}$ & $\mathrm{S}$ & $\mathrm{S}$ & $\mathrm{S}$ & $\mathrm{S}$ & $\mathrm{S}$ & $\mathrm{S}$ & $\mathrm{S}$ \\
\hline RHA-274 & $\mathrm{R}$ & $\mathrm{R}$ & $\mathrm{S}$ & $\mathrm{S}$ & $\mathrm{S}$ & $\mathrm{R}$ & $\mathrm{R}$ & $\mathrm{S}$ & $\mathrm{R}$ \\
\hline \multicolumn{10}{|l|}{ SET 2} \\
\hline PM13 & $\mathrm{R}$ & $\mathrm{R}$ & $\mathrm{R}$ & $\mathrm{S}$ & $\mathrm{S}$ & $\mathrm{S}$ & $\mathrm{S}$ & $\mathrm{S}$ & $\mathrm{S}$ \\
\hline PM17 & $\mathrm{R}$ & $\mathrm{R}$ & $\mathrm{R}$ & $\mathrm{S}$ & $\mathrm{S}$ & $\mathrm{R}$ & $\mathrm{S}$ & $\mathrm{R}$ & $\mathrm{S}$ \\
\hline 803-1 & $\mathrm{R}$ & $\mathrm{R}$ & $\mathrm{R}$ & $\mathrm{R}$ & $\mathrm{S}$ & $\mathrm{R}$ & $\mathrm{R}$ & $\mathrm{R}$ & $\mathrm{R}$ \\
\hline \multicolumn{10}{|l|}{ SET 3} \\
\hline HA-R4 & $\mathrm{R}$ & $\mathrm{R}$ & $\mathrm{R}$ & $\mathrm{R}$ & $\mathrm{R}$ & $\mathrm{R}$ & $\mathrm{R}$ & $\mathrm{R}$ & $\mathrm{R}$ \\
\hline QHP1 & $\mathrm{R}$ & $\mathrm{R}$ & $\mathrm{R}$ & $\mathrm{R}$ & $\mathrm{R}$ & $\mathrm{R}$ & $\mathrm{R}$ & $\mathrm{R}$ & $\mathrm{R}$ \\
\hline HA-335 & $\mathrm{R}$ & $\mathrm{R}$ & $\mathrm{R}$ & $\mathrm{R}$ & $\mathrm{R}$ & $\mathrm{R}$ & $\mathrm{R}$ & $\mathrm{R}$ & $\mathrm{R}$ \\
\hline CVF & 100 & 300 & 700 & 730 & 770 & 310 & 330 & 710 & 330 \\
\hline
\end{tabular}

${ }^{\mathrm{z}}$ Based on Gulya et al. (9). 
and RHA-325 (Table 1); they were assigned to race 3 (Table 2).

Characterization of virulence. CVFi values obtained for each bulk isolate of $P$. halstedii differed from the corresponding CVFt values expected according to the previous racial characterization in $42 \%$ of the cases (Table 3). Six out of the 13 isolates previously identified as race 1 had a virulence higher than expected (Table 3 ). The isolate EC496, characterized as race 4, showed a CVFi lower than 730 , because it did not cause infection on RHA-274 or PM17 (Tables 3 and 4). Isolate FA695 caused symptoms on PM17 (CVFi 330) while resistance was expected (CVFt 310) (Tables 3 and 4). The virulence values obtained for the three isolates of race 10 tested showed CVFi values of 703 .

The attempts to obtain ss isolates resulted in 0 to $8 \%$ of inoculated seedlings showing sporulation (data not shown). The highest number of ss isolates obtained corresponded to the bulk isolate CA1095, while no ss isolate was developed from four of the 14 bulk isolates used. Thus, these four bulk isolates are omitted in Table 5, which shows CVF corresponding to each of the $s s$ isolates evaluated (CVFss).

The race designation of the bulk isolate MO196 corresponded with the CVFi. However, none of the ss isolates derived from it or from CA1095 had a CVF identical to the CVFi (values 100 and 703, respectively) (Tables 3 and 5). All the ss isolates from CA1095, except two, showed CVF lower than expected, while the virulence of ss isolates from MO196 was higher than 100 (Table 5). Two isolates of race 1 (FA195 and $\mathrm{LC195)}$ and isolates EC496 (race 4) and FA695 (race 6) yielded ss isolates that had CVF equal to the CVF of the original bulk isolates (values 310 , 310 , and 330, respectively) (Table 5). The virulence of $s s$ isolates from the bulk isolates of race 1 other than FA195, LC195, and MO196, was lower than the corresponding CVFi (Table 5).

The virulence of the $s s$ isolates was altered by freezing at $-80^{\circ} \mathrm{C}$. Stable CVF were obtained for some ss isolates from LC195, FA695, MO196, and CA1095 (Table 5). In general, the virulence of the rest of the $s s$ isolates was higher after the inoculum was frozen (Table 5).

\section{DISCUSSION}

Racial diversity of $P$. halstedii was not found in Spain until 1994 (15). In our study, different isolates belonging to races 2, 4, 6, 7, and 8 (from southern Spain), and to race 10 (northeast Spain) were identified from field samples of SDM collected between 1994 and 1998. An isolate of race 5 was also obtained from one sample that was collected at a greenhouse in Cordoba. Races 2, 4, 6, and 7 have been previously isolated in other European countries (8,23$25)$, and isolates belonging to race 8 have been identified in North America $(3,18)$, but this is the first report of the occurrence of race 8 in Europe and of races 2 to 8 in Spain. Race 5, one of the most virulent races of the pathogen, was first described in North America as a greenhouse mutation (14), and there was no reference of its occurrence elsewhere until Spring et al. (19) reported it in fields in Germany. Our results confirm the occurrence of race 5 in Europe, apparently restricted to one greenhouse in Spain. While races 6 and 7 seem to be widespread in different areas of southern Spain, race 8 was restricted to two fields in Cordoba in 1997 and 2000. SDM isolates from northeastern Spain collected in 1994, 1995, and 2000 induced a pattern of resistant/susceptible reactions on the differentials that led to the identification of a new race of the pathogen: race 10. However, race 10 from Spain seems to be similar to race $\mathrm{B}$ reported in France $(17,20)$, and it is apparently restricted to the northeastern area of the country close to the French border. This race is only distinguished from race 3 by the susceptible reactions exhibited by HAR-4, HAR-5, and QHP1.

Despite the identification of races of $P$. halstedii different from race 1 during the 7 years of study, the latter seems to be the only race identified in the central and northern sunflower-growing areas of Spain, and in some locations in southern Spain. Because the climatic conditions in spring of some of the years were not very suitable for plant infection and disease development, important epidemics of SDM might happen under more favorable conditions, as commercial hybrids grown in Spain apparently do not carry any source of resistance to races 3,4 , 5, 8, and 10 of $P$. halstedii (J. Domínguez, personal communication).

Differential line 799-1 consistently showed susceptible or resistant reactions to

Table 5. Virulence of bulk isolates and single-sporangium (ss) isolates of Plasmopara halstedii compared to the theoretical Coded Virulence Formula (CVFt) expected

\begin{tabular}{|c|c|c|c|c|c|}
\hline $\begin{array}{l}\text { Isolate of } \\
P . \text { halstedii }\end{array}$ & $\mathrm{CVFt}^{\mathrm{v}}$ & $\mathrm{CVFi}^{\mathrm{w}}$ & $\begin{array}{c}\text { Single-sporangium } \\
\text { isolate }\end{array}$ & $\operatorname{CVFss}^{\mathrm{x}, \mathrm{y}}$ & CVFss $^{* y, z}$ \\
\hline \multirow[t]{7}{*}{ FA195 } & 100 & 310 & ss $A$ & 310 & 730 \\
\hline & & & ss $B$ & 310 & 330 \\
\hline & & & ss $C$ & 310 & 730 \\
\hline & & & ss $D$ & 310 & 330 \\
\hline & & & ss $E$ & 310 & 710 \\
\hline & & & ss $F$ & 310 & 730 \\
\hline & & & ss $G$ & 310 & 330 \\
\hline \multirow[t]{4}{*}{ LC195 } & 100 & 310 & ss $A$ & 310 & 330 \\
\hline & & & ss $B$ & 310 & - \\
\hline & & & ss $C$ & 310 & 330 \\
\hline & & & ss $D$ & 310 & 310 \\
\hline \multirow[t]{2}{*}{ FA695 } & 310 & 330 & ss $A$ & 330 & 330 \\
\hline & & & ss $B$ & 330 & 330 \\
\hline 6AR196 & 100 & 310 & ss $A$ & - & 100 \\
\hline \multirow[t]{2}{*}{ 8AR196 } & 100 & 310 & ss $A$ & - & 110 \\
\hline & & & ss $B$ & - & 710 \\
\hline \multirow[t]{4}{*}{ CA196 } & 100 & 753 & ss $A$ & 710 & - \\
\hline & & & ss $B$ & - & 710 \\
\hline & & & ss $D$ & - & 700 \\
\hline & & & ss $E$ & - & 100 \\
\hline \multirow[t]{2}{*}{ MO196 } & 100 & 100 & ss $A$ & 700 & 700 \\
\hline & & & ss $B$ & 730 & 710 \\
\hline \multirow[t]{2}{*}{ 2SA196 } & 100 & 710 & ss $A$ & - & 700 \\
\hline & & & ss $B$ & - & 770 \\
\hline EC496 & 730 & 310 & ss $A$ & 310 & 130 \\
\hline \multirow{12}{*}{ CA1095 } & - & 703 & ss $A$ & 730 & 730 \\
\hline & & & ss $B$ & 330 & 330 \\
\hline & & & ss $C$ & 330 & 330 \\
\hline & & & ss $D$ & 730 & 730 \\
\hline & & & ss $E$ & 330 & 330 \\
\hline & & & ss $F$ & 310 & 330 \\
\hline & & & ss $G$ & 310 & - \\
\hline & & & ss $H$ & 310 & - \\
\hline & & & ss I & 310 & 730 \\
\hline & & & ss $J$ & 330 & 730 \\
\hline & & & ss $K$ & 310 & 330 \\
\hline & & & ss $L$ & 330 & 731 \\
\hline
\end{tabular}

${ }^{\mathrm{v}}$ Coded Virulence Formula expected for each bulk isolate referred, according to its racial group, except for CA1095, isolate of the new race 10.

${ }^{\text {w }}$ Coded Virulence Formula obtained for each of the bulk isolates evaluated.

x Coded Virulence Formula obtained for each ss isolate, after increase on 'IS003' susceptible seed and before storage at $-80^{\circ} \mathrm{C}$.

${ }^{y}$ Dashes correspond to missing values of CVFss or CVFss* due to the unavailability of the corresponding $s s$ isolate.

${ }^{\mathrm{z}}$ Coded Virulence Formula obtained for each ss isolate after the increase of inoculum on susceptible seed 'ISO03' and storage at $-80^{\circ} \mathrm{C}$. 
isolates belonging to races 4 and 8 , respectively. However, the resistant reaction of $799-1$ to race 7 mentioned by Gulya et al. $(6,8)$ was not homogeneous, since after inoculation with some isolates belonging to race 7 , sporulating and stunted plants were observed simultaneously with apparently resistant asymptomatic plants.

In the case of isolates MO196 and CA1095, the CVFss were not identical to the CVFt or the CVFi (only CVFi in the case of CA1095, since it is a new race). The frequent changes from 1 to 3 or 7 in the first digit of the CVF shows the inconsistency of the reaction to the pathogen exhibited by sunflower lines RHA-265 and RHA-266 as well as RHA-274 and HA-61. Similarly, the observed changes in the second digit of the CVF could be apparently attributed to differences in the reactions of line PM17 compared with the reactions of 799-1. Therefore, a revision of the differential lines used to perform the racial characterization of $P$. halstedii is needed. It is commonly assumed that RHA-274 and HA-61 carry the same source of resistance to the pathogen. However, and perhaps due to the incorporation of resistance from HA-61 to the Spanish resistant hybrids, this line shows a more distinct reaction (either resistant or susceptible) than RHA-274.

On the other hand, and similar to previous results (18), the diversity observed in the virulence of different $s s$ isolates from bulk isolates of $P$. halstedii shows the genetic heterogeneity within each bulk isolate, suggesting a diversity of genotypes existing in the field populations of the pathogen, as well as a high frequency of recombination and/or mutation of the fungus. This hypothesis is also enhanced by the diversity of virulences of $s s$ isolates before and after storage at $-80^{\circ} \mathrm{C}$. Nevertheless, a more detailed study on the virulence of ss isolates compared with that of the original bulk isolate, as well as on the effect of temperature of storage on the virulence, should be conducted.

The results of this study show the diversity of races of $P$. halstedii present in Spain. Although race 1 or 100 is still the most frequent race in the country, races 2 to 8 and 10 are widespread, and they can cause disease on genotypes carrying resistance to race 1 . Genetic heterogeneity in field populations of the pathogen (bulk isolates) has been found, suggesting the need for further studies on the mechanisms driving fungal diversity.

\section{ACKNOWLEDGMENTS}

We gratefully acknowledge the technical assistance of Robert A. Macarthur, Carmen Montoya, and M. Teresa Olmo. We also appreciate the advice of T. J. Gulya, based on his extensive experience on diseases of sunflower.

\section{LITERATURE CITED}

1. Carson, M. L. 1981. New race of Plasmopara halstedii virulent on resistant sunflowers in South Dakota. Plant Dis. 65:842-843.

2. Fernández-Martínez, J. M., and DomínguezGiménez, J. 1978. Estudios genéticos de la resistencia al mildiu en girasol (Helianthus annuиs L.). An. INIA Ser. Prod. Veg. 8:105111.

3. García, G. 1991. Race distribution and genetics of resistance to sunflower downy mildew. M.Sc. thesis. North Dakota State University, Fargo, ND.

4. García, G., and Gulya, T. J. 1991. Sunflower downy mildew race distribution in North Dakota and Minnesota. Pages 3-5 in: Proc. Sunflower Res. Workshop, 13th, Fargo, ND.

5. Gulya, T. J., Carson, M. L., and Urs, R. 1982. Race 3 sunflower downy mildew: Distribution and sources of resistance. (Abstr.) Phytopathology 72:1136.

6. Gulya, T. J., Miller, J. F., Virányi, F., and Sackston, W. E. 1991. Proposed internationally standardized methods for race identification of Plasmopara halstedii. Helia 14:1120.

7. Gulya, T. J., Rojas, R. R., and Masirevic, S. 1988. Long-term storage of Plasmopara halstedii zoosporangia in LN without cryoprotectants. Pages 38-41 in: Proc. Int. Conf., 12th, Vol II. Novi Sad, Yugoslavia.

8. Gulya, T. J., Sackston, W. E., Virányi, F., Masirevic, S., and Rashid, K. Y. 1991. New races of the sunflower downy mildew pathogen (Plasmopara halstedii) in Europe and North and South America. J. Phytopathol. 132:303-311.

9. Gulya, T. J., Tourvieille de Labrouhe, D., Masirevic, S., Penaud, A., Rashid, K., and Virányi, F. 1998. Proposal for standardized nomenclature and identification of races of Plasmopara halstedii (sunflower downy mildew). Pages 130-136 in: ISA Symposium III Sunflower Downy Mildew. T. Gulya and F. Vear, eds. Fargo ND.

10. Gulya, T. J., and Urs, R. R. 1985. A new race of sunflower downy mildew. (Abstr.) Phytopathology 75:1339.

11. Jiménez Díaz, R. M. 1973. Notas sobre la presencia en España del mildiu del girasol. An. INIA Ser. Prot. Veg. 3:95-105.

12. Jiménez Díaz, R. M., Melero Vara, J. M., Blanco López, M. A., and Trapero-Casas, A. P. 1980. El mildiu del girasol en España: situación actual. Comunicaciones INIA Ser. Prot. Veg. 11.
13. Limpert, E., and Müller, K. 1994. Designation of pathotypes of plant pathogens. J. Phytopathol. 140:346-358.

14. Ljubich, A., Gulya, T. J., and Miller, J. F. 1988. A new race of sunflower downy mildew in North America. (Abstr.) Phytopathology 78:1580.

15. Melero-Vara, J. M., Molinero-Ruiz, M. L., Merino, A., and Domínguez, J. 1996. Razas de Plasmopara halstedii presentes en España y evaluación de susceptibilidad en híbridos comerciales. Pages 7-11 in: ISA Symposium I Disease Tolerance in Sunflower. A. Pouzet, ed. Beijing, P.R. China.

16. Molinero-Ruiz, M. L., Melero-Vara, J. M., and Gulya, T. J. 1998. Pathogenic characterization of Plasmopara halstedii isolates from Spain. Pages 26-29 in: ISA Symposium III Sunflower Downy Mildew. T. Gulya and F. Vear, eds. Fargo, ND.

17. Mouzeyar, S., Philippon, J., Walser, P., Vear, F., and Tourvieille de Labrouhe, D. 1994. Sunflower resistance to French races of downy mildew (Plasmopara halstedii). Agronomie 14:335-336.

18. Rashid, K. Y. 1991. Sunflower downy mildew in Manitoba. Page 12 in: Proc. Sunflower Res. Workshop, 13th, Fargo, ND.

19. Spring, O., Miltner, F., and Gulya, T. J. 1994 New races of sunflower downy mildew (Plasmopara halstedii) in Germany. J. Phytopathol. 142:242-244.

20. Tourvieille, D., Champion, R., Vear, F., Mouzeyar, S., and Said, J. 1988. Une nouvelle race de mildiou en France. Identification, test et contrôle. Informations Techniques CETIOM 104:3-8.

21. Vear, F. 1974. Studies on resistance to downy mildew in sunflowers (Helianthus annuus L.) Pages 297-302 in: Proc. Int. Sunflower Conf., 6th, Bucharest, Romania.

22. Vear, F., and Leclercq, P. 1971. Deux nouveaux gènes de résistance au mildiou du tournesol. Ann. Amélior. Plantes 21:251-255.

23. Virányi, F., and Gulya, T. J. 1995. Inter-isolate variation for virulence in Plasmopara halstedii (sunflower downy mildew) from Hungary. Plant Pathol. 44:619-624.

24. Virányi, F., Gulya, T. J., and Masirevic, S. 1992. Races of Plasmopara halstedii in Central Europe and their metalaxyl sensitivity. Pages 865-868 in: Proc. Int Sunflower Conf., 13th, Vol I. Pisa, Italy.

25. Virányi, F., and Masirevic, S. 1991 Pathogenic races of sunflower downy mildew in Europe: Present state, problems and prospects. Helia 14:7-10.

26. Vrânceanu, A. V., and Stoenescu, F. 1970. Immunity to sunflower downy mildew due to a single dominant gene. Problème Agricole 2:34-40.

27. Zimmer, D. E., and Kinman, M. L. 1971. The inheritance of downy mildew resistance in sunflower. (Abstr.) Phytopathology 61:1026.

28. Zimmer, D. E., and Kinman, M. L. 1972. Downy mildew resistance in cultivated sunflower and its inheritance. Crop Sci. 12:749-751. 